\title{
Transparadigmatic Output-Output Correspondence: A Case Study from Ese Ejja
}

\author{
Nicholas Rolle \\ University of California, Berkeley
}

\section{Introduction}

This paper proposes a novel type of Output-Output Correspondence (OO-Corr) termed Transparadigmatic Output-Output Correspondence, which I contrast against two other types of OO-Corr. This is summarized in Table 1. One is Classic OO-Corr (case studies in Benua 1997), which involves a correspondence relation between an output (candidate) [X-Y] and another output [X], which is referred to as the base. Here, the base is a subconstituent equivalent to the morphological stem of the Output and is therefore entirely contained within the output. In this case, the output and the base share the same root/stem (the similarity condition). The second is Paradigmatic OO-Corr (Pa-OO-C), which involves correspondence between an output $[\mathrm{X}-\mathrm{A}]$ and a base $[\mathrm{X}-\mathrm{B}]$. In this type, the affixes $[\mathrm{A}]$ and $[\mathrm{B}]$ share a morphosyntactic feature $[+\mathrm{F}]$ which places them together in a morphological paradigm. Unlike Classic OO-C, the base is not strictly speaking contained within the output.

In contrast, Transparadigmatic OO-Corr (Tr-OO-C) involves a correspondence relation between an output $[\mathrm{X}-\mathrm{Y}-\mathrm{Z}]$ and a base $[\mathrm{X}-\mathrm{Z}]$. Here, the similarity condition is sharing the same root as well as the same outer morphology (e.g. same inflection), but differ in terms of an inner morphology. Tr-OO-C is distinct from Classic OO-C and $\mathrm{Pa}-\mathrm{OO}-\mathrm{C}$ in that the output and base do not share the exact same stem morphology. While Classic OO-C and Pa-OO-C are well-established in the OO-Corr literature, Tr-OO-C is not.

\begin{tabular}{|c|c|c|}
\hline OO-Corr type & Correspondence between [OUTPUT] $]_{\mathrm{X}} \leftrightarrow[\mathrm{BASE}]_{\mathrm{X}}$ & Similarity condition \\
\hline Classic OO-C & {$[\mathrm{X}-\mathrm{Y}]_{\mathrm{X}}^{\leftrightarrow}[\mathrm{X}]_{\mathrm{X}} \quad[\sqrt{-\mathrm{DERIV}}]_{\mathrm{X}} \leftrightarrow[\sqrt{ }]_{\mathrm{X}}$} & Same $\sqrt{ }$ \\
\hline $\mathrm{Pa}-\mathrm{OO}-\mathrm{C}$ & 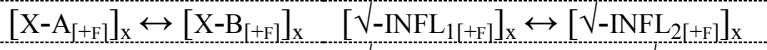 & $\{$ Same $\sqrt{ }\} \&\left\{\right.$ INFLs share $\left._{[+F]}\right\}$ \\
\hline Tr-OO-C & {$[\sqrt{ } \text {-DERIV-INFL }]_{1} \leftrightarrow\left[\sqrt{ }-\text { INFL }_{1}\right]_{\mathrm{x}}$} & $\{$ Same $\sqrt{ }\} \&\{$ Same INFL $\}$ \\
\hline
\end{tabular}

Table 1: Types of Output-Output Correspondence (OO-Corr)

This paper examines Tr-OO-C in the context of stress patterns in the Bolivian language Ese Ejja. I illustrate similarity in stress patterns between morphologically related words which is unexpected given general prosodic constraints in the language, and support the thesis that this is an example of Tr-OO-C. In short, the position of stress in verbs is largely determined idiosyncratically by inflectional morphology; however, word stress on verbs with derivational morphology remains in the same position as equivalent verbal forms without derivational morphology regardless of inflectional context. I argue that Ese Ejja is a crucial case study for Tr-OO-C, and adds to the body of evidence showing how morphologically complex forms can depend on less complex forms for the determination of their phonological shape.

\section{Output-Output Correspondence}

It has long been observed that morphologically related word forms can display phonological similarity that is unexpected given the larger phonological grammar, e.g. pre-generative works Kuryłowicz (1945),

\footnotetext{
* Primary thanks go to collaborator Marine Vuillermet (Laboratoire Dynamique Du Langage, CNRS, Lyon, France), and Ese Ejja consultants on this project, especially the late Kanono (Calixto Callaú Casirno). Thanks to support from the Berkeley community: Sharon Inkelas, Larry Hyman, Florian Lionnet, Zach O'Hagan, Brian Smith, Amalia Skilton, Andrew Garrett, Eric Wilbanks, Keith Johnson, Virginia Dawson, Lev Michael, and Chris Baier. Additional thanks to Itsik Pariente, the audiences of AMP 2017 (Nick Danis, Adam Jardine, Juliet Stanton) and NELS 2017 (Gašper Beguš, Gunnar Hansson, Rachel Walker).
}

(C) 2018 Nicholas Rolle

Proceedings of AMP 2017 
and 'cyclic'/'leveling' effects in early generative work. One prominent modern theory capturing such effects is a transderivational OT model, Output-Output Correspondence (hereafter OO-Corr) ${ }^{1}$. Under OOCorr, an output candidate is both in correspondence with an input and with another output, called the base. Faithfulness constraints can be evaluated along either of these correspondence relations. An example is below from Benua (1997:176-177). English affixes famously can either be stress-preserving (class 2, e.g. $n e s s$ ), or stress-shifting (class 1, e.g. $-a l$ ). Stress-preserving affixes are subcategorized for an output-output constraint above the markedness constraint enforcing regular English stress patterns. A shorthand for this constraint is $\mathrm{OO}_{2}$, which enforces faithfulness to the position of stress of the base. In contrast, stressshifting affixes are subcategorized for $\mathrm{OO}_{1}$ which is ranked below the markedness constraint ALIGN-R. This ranking results in stress appearing in the expected position given the phonological grammar.

\begin{tabular}{|c|c|c|c|c|c|}
\hline \multicolumn{2}{|c|}{$\begin{array}{l}\text { Base: } \\
\text { Input: }\end{array}$} & $/$ obvious + ness $_{2} /$ & ঠ & $\begin{array}{l}\frac{1}{1} \\
\frac{1}{0} \\
\frac{3}{4}\end{array}$ & రి \\
\hline $\mathrm{a}$ & & ob.(ví.ous).ness & $1 !$ & 2 & \\
\hline $\mathrm{b}$ & 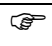 & (ób).vi.ous.ness & & 3 & \\
\hline
\end{tabular}

Table 2: Preservation of stress of base

\begin{tabular}{|c|c|c|c|c|c|}
\hline \multicolumn{2}{|c|}{$\begin{array}{l}\text { Base: } \\
\text { Input: }\end{array}$} & [ órigin ] & $\bigodot^{2}$ & $\begin{array}{l}\frac{1}{1} \\
z_{0} \\
0 \\
\end{array}$ & 8 \\
\hline $\mathrm{a}$ & 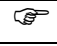 & o.(rí.gi).nal & & 2 & 1 \\
\hline $\mathrm{b}$ & & (ó.ri).gi.nal & & $3 !$ & \\
\hline
\end{tabular}

Table 3: No preservation of stress of base

Different types of OO-Corr can be identified depending on what the composition of the output and base is, and the similarity which holds between them. The English stress examples above illustrate what I term Classic OO-Corr. In this type, correspondence is between an output [X-Y] and a base [X], in which the base is the immediate subconstituent of the output, and is equivalent to the morphological stem. The 'similarity condition' in this example is sharing the same root original and the 'similarity imperative' is preserving the position of stress. Classic OO-Corr adheres to a strict definition of a base, e.g. the base must contain a subset of the features of the output (Kager 1999:282). Because Classic OO-Corr involves subconstituents, it directly competes with cyclicity models as discussed in sec. 4.4.

A second type is Paradigmatic OO-Corr (Pa-OO-C). This type involves correspondence between two morphologically related forms which are found in the same morphological paradigm, e.g. inflectional paradigms involving subject agreement, tense/aspect, polarity, etc. In Pa-OO-C, an output [X-A] (with suffix $-\mathrm{A}$ ) and a base $[\mathrm{X}-\mathrm{B}]$ (with suffix $-\mathrm{B}$ ) are in correspondence by virtue of sharing a root and by their suffixes sharing some feature $[+\mathrm{F}]$. Unlike Classic OO-C, in $\mathrm{Pa}-\mathrm{OO}-\mathrm{C}$ the base is not strictly speaking contained within the output either morphologically or with respect to their phonological exponents.

Hall \& Scott (2007) illustrate Pa-OO-C in dialectal German. In several dialects, /s/ becomes [J] before $\{\mathrm{t} / \mathrm{p}\}$ (e.g. < post> 'mail' rendered [poft]), dubbed 's-dissimilation'. Falkenberg German illustrates that $s$ dissimilation is blocked in certain paradigms (Hall \& Scott 2007:173, citing Tarral 1903). For example, the third singular inflected form of the verb <essen $>$ 'eat' is $[\varepsilon s-t]$, rather than the expected ${ }^{x}\left[\varepsilon \int-t\right]$ (where ${ }^{x}$ indicates not found). The authors claim this is due to an identity relation with morphologically related words in its paradigm, e.g. INFINITIVE, 1SG, IMP.SG in Table 4. If we understand this as Pa-OO-C, the standing similarity condition is sharing the root $\sqrt{ } \mathrm{EAT}$ and sharing inflectional features, which I abstractly denote as $[+\mathrm{INFL}]$ for expository purposes.

\begin{tabular}{|c|c|c|c|c|c|c|}
\hline [+INFL] & INFINITIVE & 1SG & 2SG & 3SG & IMP.SG & PST.PART \\
\hline Form & [عs-ən] & [Es-ən] & {$\left[\varepsilon-\int t\right]$} & {$[\varepsilon s-t]\left({ }^{x}\left[\varepsilon \int-t\right]\right)$} & {$[\varepsilon s]$} & [gəsas] \\
\hline
\end{tabular}

\section{Transparadigmatic Output-Output Correspondence}

This paper introduces Transparadigmatic Output-Output Correspondence (Tr-OO-C). This type involves correspondence between an output $[\mathrm{X}-\mathrm{Y}-\mathrm{Z}]$ and a base $[\mathrm{X}-\mathrm{Z}]$, in which the forms share the same

\footnotetext{
${ }^{1}$ Important works on OO-Corr include Kenstowicz (1996), Benua (1997), Burzio (1998, 2003, a.o.), Kager (1999), Steriade (2000), Alderete (2001), Downing et al.'s (2005) collection (e.g. McCarthy 2005), among others. Benua (1997:6) summarizes transderivational analysis in pre-OT work (e.g. Harris 1973, Hock 1973, Chung 1983).
} 
root as well as share the same outer morphology, but differ in terms of an inner morphology. An example comes from overapplication of ' $l$-vocalization' in Brazilian Portuguese (Ranier 1995, Benua 1997:237-240, Bachrach \& Nevins 2008), shown in Table 5. The phoneme /l/ becomes [i] before [s] (e.g. <jornal> 'newspaper' is <jorna[i]-s> before plural $-s$ inflection). This root may appear with the diminutive derivational morph -zinho. When this derivational form appears with inflectional $-s$, $l$-vocalization overapplies and the root still surfaces as $<$ jorna[i] $>$ even though it is not before [s]. Schematically, there is correspondence between $\left[\sqrt{\mathrm{X}}-\mathrm{Z}_{\mathrm{INFL}}\right]_{\mathrm{X}}$ and $\left[\sqrt{\mathrm{X}}-\mathrm{Y}_{\mathrm{DERIV}}-\mathrm{Z}_{\mathrm{INFL}}\right]_{\mathrm{X}}$, resulting in uniform $l$-vocalization.

\begin{tabular}{|c|c|c|c|c|}
\hline & $\varnothing$ & -zinho DIM & Schemat & cally \\
\hline SING -Ø & jornal & jornal-zinho & $\sqrt{\mathrm{X}}$ & $\sqrt{X}-Y_{\text {DERIV }}$ \\
\hline PL $-S$ & jorna $[\mathrm{i}]-\mathrm{s}$ & jorna[i]-zinho-s ${ }^{\mathrm{x}}$ (jornal-zinho-s) & $\sqrt{X-Z_{I N F L}}$ & $\sqrt{X-Y_{\text {DERIV }}-Z_{\text {INFL }}}$ \\
\hline
\end{tabular}

Table 5: Overapplication of Brazilian Portuguese $l$-vocalization (Bachrach \& Nevins 2008)

The rubik's cube diagram in Figure 1 illustrates the difference between paradigmatic Pa-OO-C and transparadigmatic Tr-OO-C. Under Pa-OO-C, there is correspondence among cells within the same paradigm, by virtue of their morphology sharing some feature [+F]. In the figure, a paradigm is signaled by having the same color, and potential cells in paradigmatic correspondence are connected by the checked black arrows. Under Tr-OO-C, there is correspondence across counterpart cells in equivalent paradigms, e.g. by virtue of sharing the exact same inflectional morphology. Potential cells in transparadigmatic correspondence are connected by the solid red arrows.

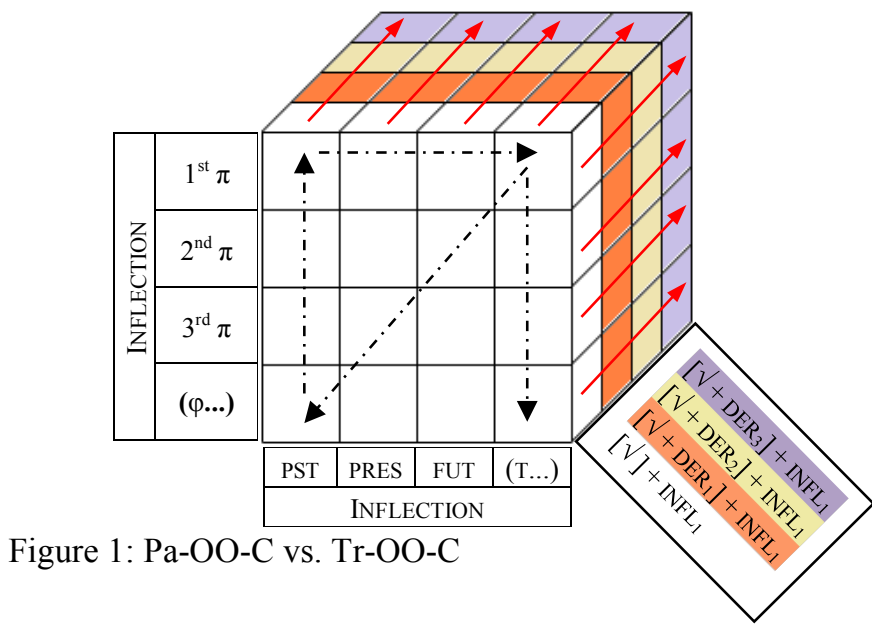

Tr-OO-C is like Pa-OO-C in that part of the similarity condition involves affixal material, and is like Classic OO-C in that the base is contained within the output, albeit not as an immediate subconstituent per se. Tr-OO-C is distinct from both in that the output and the base do not share the same stem morphology.

Early work in OO-Corr supported Tr-OO-C though not in name (Burzio 1994, 1998, 2003, 2005; Kenstowicz 1996). In general, Tr-OO-C has not been effectively established in the literature. Benua (1997:32) overtly dismisses such correspondence, e.g. she predicts that correspondence between words by virtue of sharing the same affix such as \{san-ity, brev-ity, obes-ity $\}$ to be impossible. I contend that other examples of Tr-OO-C exist, including spirantization overapplication in causatives in Cibemba [ISO-code: bem] (Hyman 1994, 2003) and causative stem uniformity in the related Bantu language Jita [jit] (Downing 2005), illustrated in the table below. In Cibemba, the causative suffix /-i/ causes spirantization of the stem, /leep $+-i / / \rightarrow$ leef- $i$ 'lengthen'. Spirantization applies even if the root and /-i / are separated by the derivational marker /-el/, e.g. leef-e $\int-i$ 'lengthen for/at' in which the output's root shape is identical to the base's root shape (Hyman 1994 analyzes this as morphology/phonology interleaving with interfixation of medial/-el/). In Jita, there is also Tr-OO-C between an output and a base involving equivalent morphology. However, here the similarity imperative is the entire stem shape not merely the shape of the root, resulting in doubling of the causative affix with the form surfacing as /gur-an-j-a/ $\rightarrow$ [gus-j-an-j-a] 


\begin{tabular}{|c|c|c|c|c|}
\hline Tr-OO-C & Output & Base & Schema & Sim. Imp. \\
\hline $\begin{array}{l}\text { Cibemba } \\
\text { Spirantization } \\
\text { Overapplication }\end{array}$ & $\begin{array}{l}\text { /leep-+-el+-ij+-a/ } \\
{\left[\text { leef-e } \int-j-a\right]_{\mathrm{x}}} \\
\left({ }^{\mathrm{x}}[\text { leep-e }-\mathrm{e}-\mathrm{j}-\mathrm{a}]\right)\end{array}$ & $\begin{array}{l}/ \text { leep-+-ij+-a/ } \\
{[\text { leef-j-a }]_{x}}\end{array}$ & {$\left[\underline{R}_{1}-D_{2}-D_{1}-I\right]_{x} \leftrightarrow\left[\underline{R}_{1}-D_{1}-I\right]_{x}$} & $\underline{\text { Root shape }}$ \\
\hline $\begin{array}{l}\text { Jita Causative } \\
\text { Stem Uniformity }\end{array}$ & $\begin{array}{l}\text { gur-an-j-a/ } \\
\text { [gus-j-an-j-a }]_{x} \\
\left({ }^{\mathrm{x}}[\text { gur } \sim \text { gus-an-j-a }]\right)\end{array}$ & $\begin{array}{l}\text { /gur-j-a/ } \\
\text { [gus-j-a }]_{x}\end{array}$ & {$\left[\underline{R}_{1}-\mathrm{D}_{1}-\mathrm{D}_{2}-\mathrm{D}_{1}-\mathrm{I}\right]_{\mathrm{x}} \leftrightarrow\left[\mathrm{R}_{1}-\mathrm{D}_{1}-\mathrm{I}\right]_{\mathrm{x}}$} & $\underline{\text { Stem shape }}$ \\
\hline
\end{tabular}

Table 6: Tr-OO-C in Bantu

Two other examples which can be subsumed under Tr-OO-C are Hungarian inflection allomorphy restrictions ('Weak Paradigmatic Uniformity' - Rebrus \& Törkenczy 2005:283-286)', and Modern Hebrew pharyngeal vocalization ('Grammatical Paradigm Uniformity' - Pariente 2012) ${ }^{3}$. The next section further supports Tr-OO-C with evidence from the position of primary stress in Ese Ejja.

\section{Case study from Ese Ejja}

4.1 Basics of Ese Ejja word prosody Ese Ejja [ese] is a Tacanan language spoken in Peru and Bolivia. Syllables are simplex, with the language having no consonant clusters or codas. There are 4 vowels /i e a o/ and 3 diphthongs /ia io oe/ <ya yo we>; adjacent vowels are treated as separate vowels ${ }^{4}$. Ese Ejja is a polysynthetic language containing at least 14 morphological slots in the verbal word, with interleaved inflectional and derivational morphology (see Table 13 in the appendix). All verbs must appear with an inflection in order to be well-formed. The basics of Ese Ejja prosody has been previously described and analyzed in Vuillermet (2012), Rolle (2016), and Rolle \& Vuillermet (in press). This paper only discusses verbal prosody; for nominal prosody see Vuillermet (2012:200-204) and Rolle (2016:3-4).

Each phonological word is marked by primary stress (= primary prominence) on one of the first three syllables, a rare left-edge three-syllable window (Caballero 2011, Kager 2012). The position of primary stress is conditioned by the factors in (1). This algorithm makes a distinction between abstract phonological accent assigned by the morphology and surface primary stress, whose main acoustic correlates are higher pitch and greater intensity (see Vuillermet 2012 for details).

(1) Primary stress conditioning factors

a. [1] the transitivity of the verb root

b. [2] abstract phonological accents assigned by obligatory inflectional affixes

c. [3] iterative trochaic or iambic feet, conditioned by the inflectional affix

d. [4] a leftmost constraint aligning primary stress with the leftmost phonological accent

\footnotetext{
${ }^{2}$ Rebrus \& Törkenczy (2005:285) discuss the lack of a $\{-k \sim-m\}$ allomorphy alternation in 1SG INDEFINITE CONDITIONAL verb forms in Hungarian, which is predicted given other paradigmatic uniformity/distinctiveness constraints. To account for this, they posit Weak Paradigmatic Uniformity and a constraint WEAKPAR ('no lexical allomorphy within a specific cell of a given paradigm'). Uniformity here can be understood as enforcing morpheme shape across equivalent paradigm cells, which I take to be transparadigmatic correspondence.

${ }^{3}$ In Modern Hebrew, pharyngeal sounds have vocalized/fronted such that $* \varsigma>\{[a], \varnothing\}$ and $* \hbar>\{[a x],[x]\}$. Pariente (2012) illustrates that the distribution of this sound change is constrained by transparadigmatic correspondence, which he terms 'Grammatical Paradigm Uniformity'. Modern Hebrew has consonantal roots and inflectional templates familiar in Semitic, e.g. / $\left\{\int, \mathrm{t}, \mathrm{k}\right\} /+/$ hi-CCvC/ $\rightarrow$ [hif.tík] 'he silenced'. If a historical pharyngeal belongs to a consonantal root, it will surface as $[\mathrm{a}] /[\mathrm{ax}]$ if the corresponding consonant appears in a moraic position, and as $\emptyset /[\mathrm{x}]$ if the corresponding consonant is non-moraic. For example, the pharyngeal *؟ surfaces as $\varnothing$ in $/\{* \uparrow, n, g\} /+/ \mathrm{CvCvC} / \rightarrow$ [ ${ }^{\varnothing}$ óneg] because it corresponds to a non-moaric consonant in a base, e.g. [k] in $/\left\{\mathrm{k}, \mathrm{d}, \int\right\} /+\mathrm{CvCvC} \rightarrow$ [kó.de $\left.\int\right]$. In contrast, the pharyngeal $* \mathrm{~S}$ surfaces as moraic $[\mathrm{a}]$ in $/\left\{\int, \mathrm{v}, * \mathrm{q}\right\} /+/ \mathrm{CvCvC} / \rightarrow\left[\int \mathrm{a} . v \mathrm{u} . \mathrm{a}\right]$ as it corresponds to moraic consonant in its base, e.g. [J] in $/\left\{\mathrm{k}, \mathrm{d}, \int\right\} /+\mathrm{CvCvC} \rightarrow$ [kó.de $]$ ]. Pariente takes this as showing correspondence between words sharing 'morphological structure' (i.e. the same inflection), but not sharing the same root, schematically $\left[\mathrm{R}_{1}-\mathbf{I}_{\mathbf{1}}\right]_{\mathrm{X}}$ $\leftrightarrow\left[R_{2}-\mathbf{I}_{1}\right]_{\mathrm{x}}$. Here, the similarity condition is the inflectional template and the similarity imperative is maintaining the moraicity of the corresponding consonants across consonantal roots.

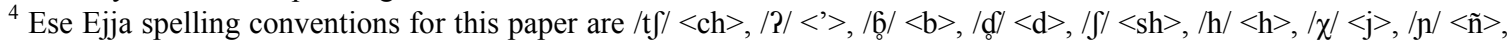
$/ \mathrm{j} /<\mathrm{y}>$, based on Rolle \& Vuillemet (in press). The spelling 'Ese Ejja' with $<\mathrm{jj}>$ as $/ \chi /$ reflects recent community practices.
} 
Vuillermet shows that these patterns are robust and consistent across a corpus of 2000 verbal forms of elicited data (see Vuillermet 2012:224-257 for details on the corpus, including further translations, accent paradigms, and subsequent discussion). Sample derivations are below.

At a root-/category-defining-level, transitive roots bear a phonological accent on the final syllable but intransitive verbs do not. This is termed transitive accent (indicated with a wavy underline). [Note that these forms represent 'intermediate' forms in the sense that they are never pronounced as such in isolation, and require additional morphology.]

(2) Transitive accent
Intransitive
Transitive
a. $1 \sigma$ pa- 'cry'
kwyá- 'hit X'
b. $2 \sigma$ besa- 'bathe'
baná- 'sow X'
c. $3 \sigma$ towaa- 'jump'
ishe'á- 'wait for X'

The third person agreement/index suffix $-k a 3 \mathrm{~A}$ assigns accent to the first syllable of the stem, termed indexical accent (indicated with a double underline). Indexical accent is dominant (Inkelas 1998) in that it overwrites transitive accent and thereby neutralizes the accentual differences between transitive and intransitive roots. [Note again that these are 'intermediate' forms never pronounced in isolation.]

(3) Indexical accent with suffix $-k a$ Intransitive
a. $1 \sigma$ pa- $+\#$...-ka
b. $2 \sigma$ besa- $+\#$...-ka
c. $3 \sigma$ towaa- $+\# \underline{\underline{e}} . .-\mathrm{ka}$
$\rightarrow$ pá-ka-
$\rightarrow$ bésa-ka-
$\rightarrow$ tówaa-ka-
kwyá- $+\#$ e...-ka $\rightarrow$ kwyá-ka-
baná- $+\#$....ka $\rightarrow$ bána-ka-
ishe’á- $+\# \underline{\underline{e}}$...-ka $\rightarrow$ íshe'a-ka-

Transitive

Inflectional tense/mood suffixes assign accent to a position within the stem, forming different suffix accent groups (SAGs) depending on their properties. SAGs 1 and 3 (mood suffixes) assign an accent to the final syllable of the stem, whereas SAGs 2 and 4 (tense suffixes) assign an accent to the penultimate syllable of the stem. SAG 1 enforces iambic feet while SAGs 2/3/4 enforce trochaic feet (Ese Ejja is a 'Dual Rhythm' language - Goedemans \& van der Hulst 2013). This accent is termed tense/mood accent (indicated with a dotted underline in Table 7 below). For a full list of such suffixes, see Table 14 in the Appendix.

\begin{tabular}{|c|c|c|c|c|c|c|c|c|}
\hline SAG & $1 \sigma$ & $2 \sigma$ & $3 \sigma$ & Tense/moo & suffix & Position & Foot & Resolution \\
\hline 1 & pá-me & besá-me & towaá-me & -ீ) me & POT1 & Ultima & Iamb & Rightmost \\
\hline 2 & pá-nahe & bésa-nahe & towáa-nahe & - 'ি nahe & PST & Penult & Trochee & Recessive \\
\hline 3 & pá-kyae & beșá-kyae & towaá-kyae & - (́k kyae & РОТ2 & Ultima & Trochee & Recessive \\
\hline 4 & pá-he & bésa-he & towáa-he & -(6) he & FUT & Penult & Trochee & Rightmost \\
\hline
\end{tabular}

Table 7: Tense/mood accent with intransitive roots (Intermediate forms)

When more than one morpheme is present which assigns morphological accent, they are in competition due to culminativity, requiring resolution. SAGs 2 and 3 are recessive, meaning that they only assign morphological accent if no other accent is already present in the stem. In contrast, SAGs 1 and 4 are rightmost-preserving, meaning that the rightmost of the two morphological accents wins. This resolution results in only a single accent surviving.

Finally, iterative footing is enforced based on the position of accent (post-resolution), shown in Table 8. In all of these cases, it is the leftmost foot in the word which receives primary stress. Primary stress does not necessarily line up to the position of morphological accent, though it is always dependent on it (termed 'rhythmic repair' of morphological accent outside a metrical window in Rolle 2016). The forms in the rightmost column match the attested surface patterns in the 2000 verb corpus mentioned above (full accent paradigms are in Table 15 and Table 16 in the Appendix). This algorithm is therefore successful in generating the correct forms for inflected verbs. 


\begin{tabular}{|c|c|c|c|c|}
\hline SAG & Stem type & $\begin{array}{c}\text { Accent position } \\
\text { (post-resolution) }\end{array}$ & Iterative footing & Leftmost $=$ Primary Stress \\
\hline \multirow{3}{*}{1} & Intransitive & towaá-me & to.(wa.á).me & to.(wa.' $\underline{\mathbf{a}}) . \mathrm{me}$ \\
\hline & Transitive & ishe'á-me & i.(she.’á).me & i.(she.' 'a).me \\
\hline & Root $+-k a$ & ishe’a-ká-me & (i.shé).('a.ká).me & (i. 'she).('a.ka).me \\
\hline \multirow{3}{*}{2} & Intransitive & towáa-nahe & to.(wá.a).(ná.he) & to.('wa.a).(na.he) \\
\hline & Transitive & ishe’á-nahe & (1́.she).('á.na).he & ('i.she).('a.na).he \\
\hline & Root $+-k a$ & íshe’a-ka-nahe & (1́.she).('á.ka).(ná.he) & ('i.she).('a.ka).(na.he) \\
\hline \multirow{3}{*}{3} & Intransitive & towaá-kyae & (tó.wa).(á.kya).e & ('to.wa).(a.kya).e \\
\hline & Transitive & ishe’á-kyae & (1́.she).('á.kya).e & ('i.she).('a.kya).e \\
\hline & Root $+-k a$ & íshe’a-ka-kyae & (1́.she).('á.ka).(kyá.e) & ('i.she).('a.ka).(kya.e) \\
\hline \multirow{3}{*}{4} & Intransitive & towáa-he & to.(wá.a).he & to.('wa.a).he \\
\hline & Transitive & ishe’á-he & (í.she).('á.he) & ('i.she). ('a.he) \\
\hline & Root $+-k a$ & ishe’á-ka-he & (í.she).('á.ka).he & ('i.she).('a.ka).he \\
\hline
\end{tabular}

Table 8: Iterative feet with leftmost foot receiving primary stress (examples with $3 \sigma$ roots)

4.2 Ese Ejja prosody with derivational morphology This algorithm, however, cannot account for the prosodic patterns of verbs which contain derivational morphology, making the wrong predictions. I exemplify this with the derivational morphemes in (4). ${ }^{5}$ These appear in distinct morphological slots within a verbal word (see Table 13 in the Appendix). As mentioned above, derivational and inflectional morphology are interleaved.

(4) Derivational morphemes examined in this study

$\begin{array}{llll} & \text { Affix } & \text { Translation } & \text { Morph. slot } \\ \text { a. } & - \text { REDUP } & \text { detransitivizer (root reduplication) } & {[+1]} \\ \text { b. } & - \text { hya } & \text { associative motion marker, 'go(O), away' } & {[+5]} \\ \text { c. } & - \text { yo } & \text { telicity marker, 'completely' } & {[+9]}\end{array}$

Table 9 (p. 7) illustrates their prosodic complications, illustrated with three different suffix accent groups. The second column 'Root + Inflection' recaps normal prosodic operations with what I call the 'inflectional forms'. The first example involves the transitive root jeki- 'go get' plus inflection (third person indexical $k a 3 \mathrm{~A}$ and mood suffix -me POT1). The algorithm detailed above results in primary stress on the third syllable of the word. Staying within this column, the second example involves the intransitive root besa'bathe' and tense suffix - nahe PST, and results in primary stress on the first syllable of the word. The third example involves jeki-again, indexical $-k a$ and tense -ani PRES, with primary stress on the second syllable. In all of these cases, the algorithm detailed above correctly predicts the location of primary stress.

We can compare this to the minimally different forms under 'Root + Derivation + Inflection' which I refer to as 'derivational forms'. This is illustrated with derivational morphemes -hya and -'yo which are boxed for clarity. Here, the derivational forms occur with primary stress on an unexpected position according to the algorithm laid out above. In the first example, we expect primary stress to be on the second position which is contrary to fact, ${ }^{\mathrm{x}}$ [je. ' ki-hya-ka-me] (where ${ }^{\mathrm{x}}$ indicates not attested); instead it appears on the third syllable [je.ki-'hya-ka-me]. The stem for inflection here is [vje.ki-hya-] consisting of the root (greyed out) and the derivational morpheme (boxed). We can compare this three-syllable stem to a threesyllable root [vi.she.'a-] in the same exact context. In this case, the three-syllable root does appear with the expected surface stress [ ${ }^{1}$ i.' she.'a-ka-me], unlike with the derivational form. Parallel unexpected surface forms are found for the other rows as well, involving different SAGs 2 and 4.

\footnotetext{
${ }^{5}$ There are 40-50 derivational morphemes in the language as well as productive root incorporation. It should be noted that the prosodic patterns of the majority of these constructions have not yet been systemically assessed.
} 


\begin{tabular}{|c|c|c|c|}
\hline \multirow{2}{*}{ SAG } & \multirow{2}{*}{$\begin{array}{c}\text { Root + Inflection } \\
\text { ('Inflectional Forms') }\end{array}$} & \multicolumn{2}{|c|}{ Root + Derivation + Inflection ('Derivational Forms') } \\
\hline & & & \\
\hline 1 & 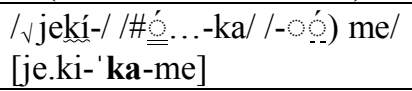 & 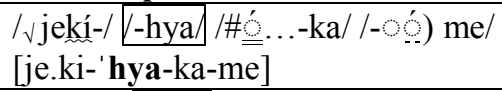 & $\begin{array}{l}\text { e] } \\
\text { me]) }\end{array}$ \\
\hline 2 & $\begin{array}{l}/ \sqrt{ } \text { besa- } \\
{[\text { 'be.sa- }}\end{array}$ & $\begin{array}{l}\text { /」 besa-//-'yo//-(o nahe / } \\
\text { ['be.sa-'yo-na.he] }\end{array}$ & $\begin{array}{l}\text { '[vbe.' sa-'yo-na. } \\
\text { (Cf. [vto.'wa.a-n }\end{array}$ \\
\hline 4 & 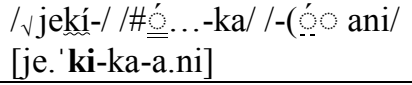 & 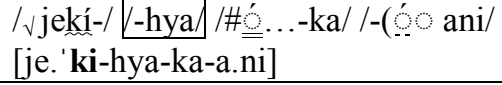 & $\begin{array}{l}\text { '[ }\left[v^{\prime} \text { je.ki-hya-ka-a.ni }\right] \\
\text { (Cf. }\left[v^{\prime} \text { i.she.'a-ka-a.ni] }\right)\end{array}$ \\
\hline
\end{tabular}

Table 9: Unexpected position of primary stress with derivational forms

An important generalization can be made despite the attested surface forms being unexpected. In each of these examples, the position of primary stress in the derivational form matches the position in the inflection form (appearing without derivational morphology), as defined from the left edge. That is, stress is consistent across forms on the third, first, or second syllable respectively. I refer to this generalization informally as 'derivational stress uniformity':

(5) Ese Ejja derivational stress uniformity - The surface position of stress in derivational forms which appear with both inflectional and derivational morphology is identical to the position of stress in the equivalent inflection form which appears without derivational morphology

From the available corpus of Ese Ejja verbal words, this generalization is robust, with only one counterexample found for forms with one of these three derivational morphemes, shown in Table $10 \mathrm{pg}$. 8). This table is split between the four distinct suffix accent groups exponing tense/mood. Each SAG includes inflected stems with intransitive (I) and transitive roots (T) of 1 to 2 syllables, and stems with and without indexical $-k a 3 \mathrm{~A}$. This generalization holds over all of these contexts.

In this table, I refer to the inflectional form as the 'inflectional base'. The position of primary stress in the inflectional base is indicated under the ' $\sigma$ column. Following these columns are the attested derivational forms, showing stress patterns equivalent to their inflectional base. Note that in these cases, the inflectional base always matches with respect to root transitivity, syllable count, and inflection class, but due to accidental gaps in the corpus the base does not necessarily contain the exact same root or the exact same inflectional morpheme. Therefore, the inflectional base should be seen as an abstraction of the actual base. Dark greyed out cells indicate impossible forms, and blank cells indicate possible forms for which I do not yet have data. In total, this table clearly illustrates derivational stress uniformity operating in Ese Ejja.

4.3 Derivational stress uniformity as Tr-OO-C This subsection supports the thesis that Ese Ejja derivational stress uniformity is an example of Transparadigmatic Output-Output Correspondence (Tr-OOC). Recall that Tr-OO-C was defined as correspondence across counterpart cells in equivalent paradigms, e.g. $[\mathrm{X}-\mathrm{Y}-\mathrm{Z}]_{\mathrm{x}} \leftrightarrow[\mathrm{X}-\mathrm{Z}]_{\mathrm{x}}$. With respect to the EE, this amounts to a correspondence between $\left[\mathrm{V}-\mathrm{DERIV}-\mathrm{INFL}_{1}\right]_{\mathrm{X}}$ $\leftrightarrow\left[\mathcal{V}-\mathrm{INFL}_{1}\right]_{\mathrm{x}}$ in which the similarity condition is having the same root and inflection and the similarity imperative is maintaining the position of primary stress with respect to the left word edge.

I implement this Tr-OO-C analysis via Agreement-By-Correspondence (ABC - Rose \& Walker 2004). There has been recognition in the literature of the similarities between Output-Output Correspondence and Agreement-By-Correspondence (Hansson 2007:405, fn 8), but no direct implementation to date to my knowledge. Within $\mathrm{ABC}$, there is a correspondence relation $\mathrm{C}_{\mathrm{x}}$ based on the similarity condition, enforced via a constraint of a type CORR-CC $\mathrm{C}_{(\mathrm{s}-\mathrm{COND})}$. Further, the similarity imperative is understood as an agreement relation between correspondents, of a type IDENT-CC $\mathrm{CS}_{(\mathrm{SIMP})}$. A toy example is an input / $\mathrm{fak}$-is/ mapped to an output $\left[\int_{\mathrm{x}} \mathrm{ak}-\mathrm{i} \int_{\mathrm{x}}\right]$, involving a correspondence relation CORR-CC $\mathrm{C}_{[\mathrm{S \textrm {si }}])}$ for the sibilants $\left\{\mathrm{s}, \int\right\}$ and an agreement constraint ID-CC $\mathrm{C}_{[\text {[ANT] }]}$ for anteriority value.

In Ese Ejja, correspondence is between the inflectional base (B) and a derivational output (O). The constraints CORR-BO ${ }_{(\mathrm{ROOT})}$ and CORR-BO $\mathrm{(INF)}_{\text {in }}$ (6) (pg. 9) enforce correspondence to a base which shares the same root (besa- 'bathe') and also shares the same inflection (-nahe PST). The faithfulness constraint ID$\mathrm{BO}_{\text {(STRESS) }}$ enforces correspondents to have the same position of primary stress, in (6) on the first syllable. Additional constraints are LEFTMOST ('the leftmost foot in the word is the head foot'), MAX-IO ('Input segments have output segments'), and ACCENT-TO-STRESS ('Accent corresponds to phonetic stress'). 


\begin{tabular}{|c|c|c|c|c|c|c|c|c|}
\hline \multicolumn{2}{|c|}{ INFL } & \multirow{2}{*}{$\begin{array}{l}\text { Inflectional base } \\
{[\text { 'pa-me }]}\end{array}$} & \multirow{2}{*}{$\frac{\text { ' }}{21^{\text {st }}}$} & \multirow{2}{*}{$\begin{array}{l}\text { Detransitivizing -REDUP [+1] } \\
\text { ['hyo-hyo-me] } \\
\text { ['hyo-hyo-cha.na] }\end{array}$} & \multicolumn{2}{|c|}{ Associated motion -hya 'go (O)' $[+5]$} & \multicolumn{2}{|c|}{ Aspect -'yo TELIC 'completely' [+9] } \\
\hline \multirow{6}{*}{ 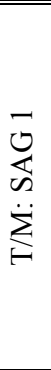 } & I & & & & & & ['pwe-'yo-kwe] & \\
\hline & $\mathrm{T}$ & ['kwya-me] & $1^{\mathrm{st}}$ & & ['mo-hya-me] & & & \\
\hline & $-k a$ & [pa-'ka-me] & $2^{\text {nd }}$ & $\begin{array}{l}\text { [hyo-'hyo-ka-me] } \\
\text { [hyo-'hyo-ka-cha.na] }\end{array}$ & [mo-'hya-ka-me] & & $\begin{array}{l}\text { [hya-'ka-'yo-me] } \\
\text { [mo-'ka-'yo-me] }\end{array}$ & [kwya-'ka-'yo-me] \\
\hline & I & [be.'sa-me] & $2^{\text {nd }}$ & [kwa.' kwa-kwa.kwa-cha.na] & & & & \\
\hline & $\mathrm{T}$ & [ba.'na-me] & $2^{\text {nd }}$ & & $\begin{array}{l}{[\text { si.'po-hya-me }]} \\
{[\text { o.'ja-hya-cha.na] }}\end{array}$ & [wo.' o-hya-me] & [wa.'na-'yo-kwe] & [da.'sya-'yo-me] \\
\hline & $-k a$ & [be.sa-'ka-me] & $3^{\text {rd }}$ & [kwa.kwa-'kwa.kwa-ka-cha.na] & [si.po-'hya-ka-me] & [o.ja-'hya-ka-cha.na] & [i.shwa-' ka-'yo-me] & [i.jya-' ka-'yo-cha.na] \\
\hline \multirow{6}{*}{ 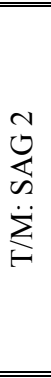 } & II & ['pa-na.he] & $1^{\text {st }}$ & ['hyo-hyo-na.he] & & & & \\
\hline & $\mathrm{T}$ & ['kwya-na.he] & $1^{\text {st }}$ & & ['mo-hya-na.he] & & ['kwya-'yo-na.he] & \\
\hline & $-k a$ & ['pá-ka-na.he] & $1^{\text {st }}$ & ['hyo-hyo-ka-na.he] & ['mo-hya-ka-na.he] & & ['kwya-ka-'yo-na.he] & ['mo-ka-'yo-na.he] \\
\hline & I & ['be.sa-na.he] & $1^{\text {st }}$ & ['kwa.kwa-kwa.kwa-na.he] & & & $\begin{array}{l}\text { ['be.sa-'yo-na.he] } \\
\text { ['do.bi-'yo-na.he] }\end{array}$ & $\begin{array}{l}\text { ['kwa.ya-'yo-na.he] } \\
\text { ['o.she-'yo-na.he] }\end{array}$ \\
\hline & $\mathrm{T}$ & [ba.'na-na.he] & $2^{\text {nd }}$ & & [si.'po-hya-na.he] & [wo.' o-hya-na.he] & $\begin{array}{l}\text { [ba.'na-'yo-na.he] } \\
\text { [da.'wa-'yo-na.he] }\end{array}$ & $\begin{array}{l}\text { [i.'jya-'yo-na.he] } \\
\left({ }^{\otimes}[\text { 'bo.bya-'yo-na.he] })\right.\end{array}$ \\
\hline & $-k a$ & ['be.sa-ka-na.he] & $1^{\text {st }}$ & ['kwa.kwa-kwa.kwa-ka-na.he] & ['si.po-hya-ka-na.he] & ['o.ja-hya-ka-na.he] & $\begin{array}{l}\text { ['bo.bya-ka-'yo-na.he] } \\
\text { ['i.shwa-ka-'yo-na.he] }\end{array}$ & ['ka.wi-ka-'yo-na.he] \\
\hline \multirow{6}{*}{ 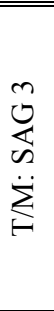 } & I & ['pa-kya.e] & $1^{\text {st }}$ & ['hyo-hyo-kya.e] & & & & \\
\hline & $\mathrm{T}$ & ['kwya-kya.e] & $1^{\text {st }}$ & & & & & \\
\hline & $-k a$ & ['pa-ka-kya.e] & $1^{\text {st }}$ & ['hyo-hyo-ka-kya.e] & & & & \\
\hline & $\mathrm{I}$ & [be.'sa-kya.e] & $2^{\text {nd }}$ & [kwa.' kwa-kwa.kwa-kya.e] & & & & \\
\hline & $\mathrm{T}$ & [ba.'na-kya.e] & $2^{\text {nd }}$ & & $\begin{array}{l}\text { [wo.' o-hya-kya.e] } \\
\text { [je.' ki-hya-kya.e] }\end{array}$ & [o.'ja-hya-kya.e] & & \\
\hline & $-k a$ & ['ba.na-ka-kya.e] & $1^{\text {st }}$ & ['kwa.kwa-kwa.kwa-ka-kya.e] & ['si.po-hya-ka-kya.e] & ['wo.o-hya-ka-kya.e] & ['i.jya-ka-'yo-kya.e] & ['sa.ha.'a-ka-'yo-kya.e] \\
\hline \multirow{6}{*}{ 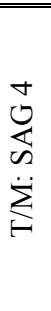 } & I I & ['pa-he] & $1^{\text {st }}$ & ['hyo-hyo-he] & & & ['pwa-he-'yo] & \\
\hline & $\mathrm{T}$ & ['kwya-ka-he] & $1^{\text {st }}$ & & ['mo-hya-je] & & & \\
\hline & $-k a$ & ['pa-ka-he] & $1^{\text {st }}$ & ['hyo-hyo-ka-he] & & & ['ba-ka-'yo-a.ni] & \\
\hline & $\mathrm{I}$ & ['be.sa-he] & $1^{\text {st }}$ & ['kwa.kwa-kwa.kwa-he] & & & ['po.ki-he-'yo] & \\
\hline & $\mathrm{T}$ & [ba.'na-he] & $2^{\text {nd }}$ & & [o.'ja-hya-he] & [si.'po-hya-a.ña] & & \\
\hline & $-k a$ & [be.'sa-ka-he] & $2^{\text {nd }}$ & [kwa.' kwa-kwa.kwa-ka-he] & $\begin{array}{l}\text { [o.'ja-hya-ka-he] } \\
\text { [da.'wa-hya-ka-a.ni] }\end{array}$ & [si.'po-hya-ka-a.ña] & [ke.' kwa-ka-he-'yo] & \\
\hline
\end{tabular}

Table 10: Derivational stress uniformity across all inflectional contexts 
(6) Tr-OO-C via $\mathrm{ABC}$ in Ese Ejja

Constraints Derivational form Inflectional base

$\begin{array}{lllll}\text { a. } & \text { ID-BO }_{(\text {STRESS }} & {[\mathrm{x} \cdot .} & \leftrightarrow & {[\mathrm{x} \cdot} \\ \text { b. } & \text { CORR-BO }_{(\mathrm{ROOT})} & {\left[(\text { 'be.sa)-('yo-na).he }]_{\mathrm{x}}\right.} & \leftrightarrow & {[\text { ('be.sa)-(na.he) }]_{\mathrm{x}}}\end{array}$

Table 11 illustrates the derivation of the verbal form [('be.sa)-(na.he)] which has only inflectional morphology. As above, the underlying form of the suffix is / - 0 nahe / which assigns an accent to the penult of the stem, in this case falling on the initial syllable (which is underlined for clarity). Going through the tableau, candidate e is eliminated because the foot with primary prominence is not leftmost in the word. Candidates b-d are eliminated because the accent does not correspond to phonetic stress. This results in candidate a as optimal. Because there is no base, the three ID- and CORR-OO constraints are not violated.

\begin{tabular}{|c|c|c|c|c|c|c|c|c|}
\hline & \multirow[b]{2}{*}{$\begin{array}{l}\text { Base: } \\
\text { Input: }\end{array}$} & \multirow[b]{2}{*}{$\begin{array}{l}\varnothing \\
\text { / besa-/ /- (́o nahe / }\end{array}$} & $\mathrm{M}$ & $\mathrm{F}$ & $\mathrm{OO}$ & $\mathrm{OO}$ & $\mathrm{OO}$ & $\mathrm{F}$ \\
\hline & & & 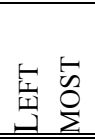 & $\frac{0}{1}$ & 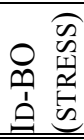 & 旁 & 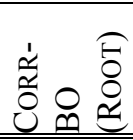 & 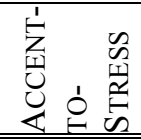 \\
\hline $\mathrm{a}$ & 蛋 & [(' & & & & & & \\
\hline $\mathrm{b}$ & & [(be. 'sa)-(na.he)] & & & & & & $1 !$ \\
\hline $\mathrm{c}$ & & [be.('sa-na).he] & & & & & & $1 !$ \\
\hline $\mathrm{d}$ & & [be.(sa-'na).he] & & & & & & $1 !$ \\
\hline $\mathrm{e}$ & & {$[($, be.sa)-('na.he $)]$} & $1 !$ & & & & & \\
\hline
\end{tabular}

Table 11: Inflectional form with no base

Table 12 illustrates the derivation of the verbal form [('be.sa)-('yo-na).he)] with the derivational morpheme -'yo, which has as its inflectional base [('be.sa)-(na.he)], derived in Table 11. As above, candidate $\mathrm{j}$ is eliminated by the LEFTMOST constraint. Candidate $\mathrm{i}$ satisfies other constraints, but violates MAX-IO by deleting the final vowel of the root. The OO constraints introduced in (6) are crucially ordered

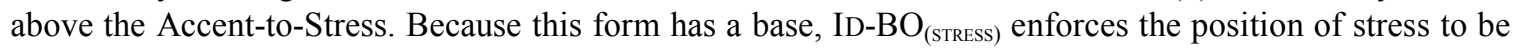
identical in corresponding output candidates. Candidates $\mathrm{f}-\mathrm{h}$ are therefore eliminated because the stress on the output candidate does not match the base. Finally, candidates b-e are eliminated because they are not in correspondence with the base even though they share the relevant morphology (indicated with subscript $\mathrm{y}_{\mathrm{y}}$ ). Candidate a is therefore optimal which does correspond to the base (indicated with subscript ${ }_{\mathrm{x}}$ ), even though it violates ACCENT-TO-STRESS (i.e. stress not corresponding to the accented syllable, underlined).

\begin{tabular}{|c|c|c|c|c|c|c|c|c|}
\hline & & & $\mathrm{M}$ & $\mathrm{F}$ & $\mathrm{OO}$ & $\mathrm{OO}$ & $\mathrm{OO}$ & $\mathrm{F}$ \\
\hline & Base: & 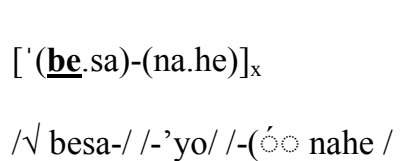 & 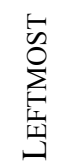 & 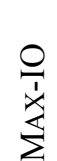 & 에 & 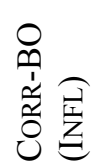 & 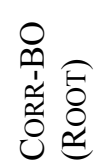 & 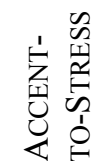 \\
\hline $\mathrm{a}$ & 承 & [('be.sa)-('yo-na).he $]_{x}$ & & & & & & 1 \\
\hline $\mathrm{b}$ & & {$\left[(\right.$ 'be.sa $)-(\text { 'yo-na).he }]_{\mathrm{y}}$} & & & & $1 !$ & 1 & 1 \\
\hline $\mathrm{c}$ & & {$\left[(\text { be. 'sa)-('yo-na).he }]_{\mathrm{y}}\right.$} & & & & $1 !$ & 1 & \\
\hline $\mathrm{d}$ & & {$[\text { be.('sa-'yo)-(na.he) }]_{\mathrm{y}}$} & & & & $1 !$ & 1 & \\
\hline $\mathrm{e}$ & & {$[\text { be.(sa-' 'yo)-(na.he) }]_{y}$} & & & & $1 !$ & 1 & 1 \\
\hline $\mathrm{f}$ & & [(be. 'sa)-('yo-na).he $]_{x}$ & & & $1 !$ & & & \\
\hline $\mathrm{g}$ & & {$[\text { be.('sa-'yo)-(na.he) }]_{x}$} & & & $1 !$ & & & \\
\hline $\mathrm{h}$ & & [be.(sa-' 'yo)-(na.he) $]_{\mathrm{x}}$ & & & $1 !$ & & & 1 \\
\hline i & & {$\left[\left(\text { bes }^{\text {t }}-' \text { yo }\right)-(\text { na.he })\right]_{x}$} & & $1 !$ & & & & \\
\hline j & & {$\left[(\right.$, be.sa) $)-(\text { 'yo-na).he }]_{x}$} & $1 !$ & & 1 & & & 1 \\
\hline
\end{tabular}

Table 12: Tr-OO-C between a derivational form and an inflectional base 
4.4 Against a cyclicity alternative I introduced above in sec. 4.1 that the derivation of Ese Ejja prosody with inflected forms without derivational morphology involves three 'layers' of accent assignment - transitive, indexical, and tense/mood - followed by footing and stress mapping. The most straightforward analysis of these facts involves a 'cyclic' model employing only input-output correspondence without appeal to OO-Corr (in other words, no transderivational influence from one word onto another) ${ }^{6}$. In contrast, I argued that OO-Corr is required to account for verbs with derivational morphology, and introduced Tr-OO-C. One alternative to the Tr-OO-C analysis is a strictly cyclic account $a ̀$ la Stratal OT for Ese Ejja inflectional and derivational verbal forms (Bermúdez-Otero 2008; Kiparsky 2015; a.o.).

I contend that strict cyclicity is unattractive for Ese Ejja derivational forms. First, in the data above it is the inflectional suffixes which assign accent to stems - they are accent triggers - while the derivational suffixes do not - they are inert/neutral. Recall the first example from Table 9 (p. 7) involving the derivational form [je.ki-'hya-ka-me] corresponding to an inflectional base [je.ki-'ka-me]. In this example, stress is maintained on the third syllable, even though it falls on distinct morphemes (the derivational morpheme - hya versus the inflectional morpheme $-k a$ ). This shows that derivational morphemes are inert but are still visible for prosodic operations - i.e. they can be the targets of stress - and therefore cannot be considered internally 'extrametrical'.

Under strict cyclicity, this would imply the following set of operations. The root merges with inflection, and inflectional morphemes assign various accents to the root/stem subject to accent resolution. Next, this 'inflectional stem' merges with derivational morphemes [If derivation merged before inflection, this would result in the wrong surface forms, as shown in rightmost column of Table 9]. Although this merge order would be typologically marked, it is not completely unwarranted given that inflectional and derivational morphology are interleaved in Ese Ejja. However, secondary merger of derivational morphemes would require derivational morphemes to be both merged late and be interfixed between the root and inflectional material (an analysis parallel to Hyman's 1994 account of Cibemba, in Table 6). Moreover, derivational morphemes would only be interfixed on the segmental tier and would not disrupt the suprasegmental tier. This is shown in (7), where the greyed out portions are the stem to which -hya is interfixed (between the root jeki- and inflectional $-k a$ ).

(7) $\left[\begin{array}{lll}. & \mathrm{x} & .\end{array}\right]$

jeki-ká-me + -hya

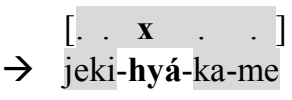

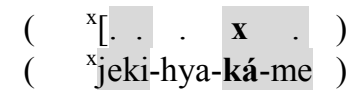

In sum, these three operations (merging inflection before derivation, interfixing derivation, and interfixing strictly on the segmental tier) would be rare individually and exceptional if sequenced together. I therefore reject this cyclicity alternative to account for Ese Ejja derivational stress uniformity.

\section{Conclusion}

This paper proposed a novel type of Output-Output Correspondence (OO-Corr) termed Transparadigmatic Output-Output Correspondence (Tr-OO-C), which I contrasted against Classic OO-Corr and Paradigmatic OO-Corr. Schematically, Tr-OO-C involves correspondence between an Output [X-Y-Z] and a base [X-Z]. I supported this typology from previous case studies in the literature, and argued for a new case of Tr-OO-C in the Bolivian language Ese Ejja involving stress uniformity between inflectional and derivational verbal forms. I referred to this as derivational stress uniformity, and showed that this generalization cannot be captured by the normal prosody of the language. Rather, I argued that derivational forms are in a correspondence relation with an inflectional base ([ $\left.\left.\sqrt{ }-\mathrm{DERIV}-\mathrm{INFL}_{1}\right]_{\mathrm{x}} \leftrightarrow\left[\sqrt{ }-\mathrm{INFL}_{1}\right]_{\mathrm{x}}\right)$, enforced by highly ranked constraints ID-BO ${ }_{(\mathrm{STRESS})}, \mathrm{CORR}-\mathrm{BO}_{(\mathrm{ROOT})}$, and CORR-BO ${ }_{(\mathrm{INFL})}$, modeled after Agreement-ByCorrespondence (Rose \& Walker 2004).

I conclude with bringing up two important residual issues. One is what happens when a verbal form with derivational morphology lacks a base due to a lexical gap. For example, several words have roots plus derivational morphology which together form an idiosyncratic meaning/collocation, sometimes with the

\footnotetext{
${ }^{6} \mathrm{I}$ have claimed that indexical accent assigned by $-k a 3 \mathrm{~A}$ is dominant, while other inflection is recessive or rightmostpreserving. I gloss over the fact that dominant affixes have been argued to involve OO-Corr, e.g. Alderete's (2001) 'Antifaithfulness' theory. For reasons of space, I leave aside these issues.
} 
root not appearing on its own. These forms display the same prosodic patterns as counterparts which $d o$ have a clear base. Second, not all derivational morphemes are as straightforward as the three presented in this study. For example, some verbal forms appearing with the causative -mee CAUS 'make' (morphological slot [+2]) cannot fully be accounted for with either the prosodic algorithm presented in sec. 4.1 for inflectional forms or the novel Tr-OO-C analysis for derivational forms. Future study is required to determine the prosodic properties of all derivational morphemes in Ese Ejja.

\section{Appendix}

\begin{tabular}{|c|c|c|c|c|c|c|c|c|c|c|c|c|c|c|}
\hline-3 & -2 & -1 & 0 & +1 & +2 & +3 & +4 & +5 & +6 & +7 & +8 & +9 & +10 & +11 \\
\hline 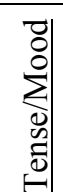 & $\frac{\vec{a}}{\frac{3}{0}}$ & 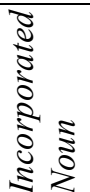 & 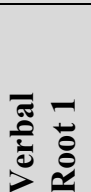 & 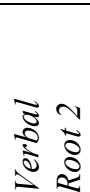 & 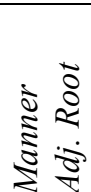 & 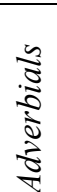 & $\frac{\overrightarrow{0}}{\frac{3}{0}}$ & 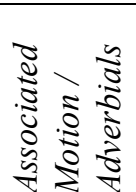 & 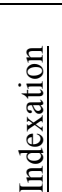 & 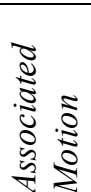 & \begin{tabular}{l|}
$\overrightarrow{0}$ \\
0 \\
$\sum_{0}$ \\
0 \\
0 \\
0 \\
0
\end{tabular} & 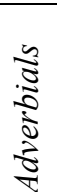 & $\begin{array}{l}\tilde{U} \\
\tilde{\Xi} \\
\tilde{\pi} \\
\tilde{\pi}\end{array}$ & 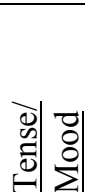 \\
\hline
\end{tabular}

Table 13: Verb template (root greyed out \& bold; inflectional slots underlined; derivational slots italicized)

\begin{tabular}{|c|c|c|c|c|}
\hline Category & Subcategory & Morpheme(s) & Morphological slot(s) & SAG \\
\hline \multirow{7}{*}{ Tense } & PRESENT & -ani $\sim$ aña & +11 & 4 \\
\hline & PRESENT & $-(\mathrm{e}) \mathrm{ki}$ & +11 & 4 \\
\hline & PRESENT & -haa & +11 & 4 \\
\hline & PRESENT & -ba'e & +11 & 4 \\
\hline & FUTURE & -he & +8 & 4 \\
\hline & REMOTE PAST & -a =pwá & $+11(+$ clitic $)$ & - \\
\hline & PAST & -(a)nahe & +11 & 2 \\
\hline \multirow{6}{*}{$\begin{array}{c}\text { Mood/ } \\
\text { Commands }\end{array}$} & PotentIAL 2 & -kyae & +11 & 3 \\
\hline & POTENTIAL 1 & - me & +11 & 1 \\
\hline & EXTERNAL OBLIGATION & $-\mathrm{ka} \ldots-. \mathrm{ji}$ & $+6 \ldots+11$ & 1 \\
\hline & IMPERATIVE & -kwe & +11 & 1 \\
\hline & ProhiBITIVE & a'a ...-ji & (particle) $\ldots+11$ & 1 \\
\hline & APPREHENSIVE & -chana & +11 & 1 \\
\hline
\end{tabular}

Table 14: List of tense/mood suffixes and which suffix accent group (SAG) they belong to

\begin{tabular}{clllll}
\hline \multirow{2}{*}{ Intransitive } & \multicolumn{1}{c}{$\begin{array}{c}\text { SAG 1 } \\
\text {-me POT1 }\end{array}$} & \multicolumn{1}{c}{$\begin{array}{c}\text { SAG 2 } \\
\text {-nahe PST }\end{array}$} & \multicolumn{1}{c}{$\begin{array}{c}\text { SAG 3 } \\
\text {-kyae POT2 }\end{array}$} & \multicolumn{1}{c}{$\begin{array}{c}\text { SAG 4 } \\
\text {-he FUT }\end{array}$} \\
\hline \multirow{2}{*}{$1 \sigma$} & $\varnothing$ & 'pa-me & 'pa-na.he & 'pa-kya.e & 'pa-he \\
& $-k a$ & pa-'ka-me & 'pa-ka-na.he & 'pa-ka-kya.e & 'pa-ka-he \\
\hline \multirow{2}{*}{$2 \sigma$} & $\varnothing$ & be.' sa-me & 'be.sa-na.he & be.'sa-kya.e & 'be.sa-he \\
& $-k a$ & be.sa-' ka-me & 'be.sa-ka-na.he & 'be.sa-ka-kya.e & be.'sa-ka-he \\
\hline \multirow{2}{*}{$3 \sigma$} & $\varnothing$ & to.wa.' a-me & to.'wa.a-na.he & 'to.wa.a-kya.e & to.'wa.a-he \\
& $-k a$ & to.'wa.a-ka-me & 'to.wa.a-ka-na.he & 'to.wa.a-ka-kya.e & 'to.wa.a-ka-he \\
\hline
\end{tabular}

Table 15: Location of primary stress with intransitive roots -4 distinct suffix accent groups (SAGs)

\begin{tabular}{clllll}
\hline \multirow{2}{*}{ Transitive } & \multicolumn{1}{c}{$\begin{array}{c}\text { SAG 1 } \\
\text {-me POT1 }\end{array}$} & \multicolumn{1}{c}{$\begin{array}{c}\text { SAG 2 } \\
\text {-nahe PST }\end{array}$} & \multicolumn{1}{c}{$\begin{array}{c}\text { SAG 3 } \\
\text {-kyae POT2 }\end{array}$} & \multicolumn{1}{c}{$\begin{array}{c}\text { SAG 4 } \\
\text {-he FUT }\end{array}$} \\
\hline \multirow{2}{*}{$1 \sigma$} & $\varnothing$ & 'kwya-me & 'kwya-na.he & 'kwya-kya.e & 'kwya-he \\
& $-k a$ & kwya-'ka-me & 'kwya-ka-na.he & 'kwya-ka.kya.e & 'kwya-ka-he \\
\hline \multirow{2}{*}{$2 \sigma$} & $\varnothing$ & ba.'na-me & ba.'na-na.he & ba.'na-kya.e & ba.'na-he \\
& $-k a$ & ba.na-'ka-me & 'ba.na-ka-na.he & 'ba.na-ka-kya.e & ba.'na-ka-he \\
\hline \multirow{2}{*}{$3 \sigma$} & $\varnothing$ & i.she.' 'a-me & 'i.she.'a-na.he & 'i.she.'a-kya.e & 'i.she.'a-he \\
& $-k a$ & i.'she.'a-ka-me & 'i.she.'a-ka-na.he & 'i.she.'a-ka-kya.e & 'i.she.'a-ka-he \\
\hline
\end{tabular}

Table 16: Location of primary stress with transitive roots -4 distinct suffix accent groups (SAGs)

\section{References}

Alderete, John. 2001. Morphologically governed accent in Optimality Theory. New York: Routledge. 
Bachrach, Asaf \& Andrew Nevins. 2008. Approaches to Inflectional Identity. In Asaf Bachrach \& Andrew Nevins (eds.), Inflectional Identity. Oxford: OUP. 1-28.

Benua, Laura. 1997. Transderivational identity: Phonological relations between words. Dissertation, UMASS Amherst. Bermúdez-Otero, Ricardo. 2008. Stratal optimality theory. Oxford: Oxford University Press.

Burzio, Luigi. 1994. Principles of English Stress. Cambridge: Cambridge University Press.

Burzio, Luigi. 1998. Multiple correspondence. Lingua 104:79-109.

Burzio, Luigi. 2003. Output-to-output faithfulness in phonology. Lingue E Linguaggio 2(1):69-104.

Burzio, Luigi. 2005. Sources of paradigm uniformity. In Laura Downing, T.A. Hall, \& Renate Raffelsiefen (eds.), Paradigms in phonological theory. Oxford: OUP. 65-106.

Caballero, Gabriela. 2011. Morphologically conditioned stress assignment in Choguita Rarámuri (Tarahumara). Linguistics 49(4):749-790.

Chung, Sandra. 1983. Transderivational relationships in Chamorro phonology. Language 59:35-66.

Downing, Laura. 2005. Jita causative doubling provides optimal paradigms. Laura Downing, T.A. Hall, \& Renate Raffelsiefen (eds.), Paradigms in phonological theory. Oxford: OUP. 122-144.

Downing Laura, T.A. Hall, \& Renate Raffelsiefen (Eds.). 2005. Paradigms in phonological theory. Oxford: OUP.

Goedemans, Rob \& Harry van der Hulst. 2013. Rhythm types. In Matthew S. Dryer \& Martin Haspelmath (eds.), The world atlas of language structures online. Leipzig: Max Planck Institute for Evolutionary Anthropology.

Hall, T.A. \& John Scott. 2007. Inflectional paradigms have a base: Evidence from s-dissimilation in Southern German dialects. Morphology 17(1):151-178.

Hansson, Gunnar Ólafur. 2007. Blocking effects in agreement by correspondence. Linguistic Inquiry 38(2):395-409.

Harris, James. 1973. On the order of certain phonological rules in Spanish. In Steve Anderson \& Paul Kiparsky (eds.), A Festschrift for Morris Halle. New York: Holt, Reinhart and Winston.

Hock, Hans. 1973. Exceptions and synchronic analogy in Sanskrit. Studies in the Linguistic Sciences 3:81-101.

Hyman, Larry. 1994. Cyclic phonology and morphology in Cibemba. In J. Cole \& C. Kisseberth (eds.) Perspectives in phonology. Stanford: CSLI publications. 81-112.

Hyman, Larry. 2003. Sound change, misanalysis, and analogy in the Bantu causative. Journal of African languages and linguistics. 24(1):55-90.

Inkelas, Sharon. 1998. The theoretical status of morphologically conditioned phonology. In Geert Booij \& Jaap van Marle (eds.), Yearbook of morphology 1997. Dordrecht: Springer Netherlands. 121-155.

Kager, René. 1999. Optimality Theory. Cambridge: Cambridge University Press.

Kager, René. 2012. Stress in windows: Language typology and factorial typology. Lingua 122:1454-1493.

Kenstowicz, Michael. 1996. Uniform exponence and base identity. In J. Durand \& B. Laks (eds.), Current trends in phonology. University of Salford Press. 363-393.

Kiparsky, Paul. 2015. Stratal OT: A synopsis and FAQs. In Yuchau E. Hsiao \& Lian-hee Wee (eds.), Capturing Phonological Shades. Cambridge/New York: Cambridge University Press. 2-44.

Kuryłowicz, Jerzy. 1945. La nature des procès dits 'analogiques'. Acta Linguistica 5:15-37.

McCarthy, John. 2005. Optimal paradigms. In Laura Downing, T.A. Hall, \& Renate Raffelsiefen (eds.), Paradigms in phonological theory. Oxford: OUP. 170-210.

Pariente, Itsik. 2012. Grammatical paradigm uniformity. Morphology 22(4):485-514.

Rainer, Franz. 1996. Inflection inside derivation: Evidence from Spanish and Portuguese. In Geert Booij \& Jaap van Marle (eds.), Yearbook of Morphology 1995. Dordrecht: Kluwer. 83-91.

Rebrus, Péter \& Miklos Törkenczy. 2005. Uniformity and Contrast in the Hungarian Verbal Paradigm. In Laura J. Downing, T. A. Hall, Renate Raffelsiefen (eds.), Paradigms in Phonological Theory. Oxford: OUP: 263-295.

Rolle, Nicholas. 2016. Rhythmic Repair of Morphological Accent Assigned Outside of a Metrical Window. In Karen Jesney, Charlie O'Hara, Caitlin Smith, \& Rachel Walker (eds.), Supplemental Proceedings of the 2016 Annual Meeting on Phonology. Washington, DC: Linguistic Society of America.

Rolle, Nicholas \& Marine Vuillermet. In press. Morphologically assigned accent and an initial three syllable window in Ese Ejja. In Rob Goedemans, Harry van der Hulst \& Jeffrey Heinz (eds.), The study of word stress and accent: Theories, methods and data. Cambridge: Cambridge University Press.

Rose, Sharon \& Rachel Walker. 2004. A typology of consonant agreement as correspondence. Language 80:475-531.

Steriade, Donca. 2000. Paradigm uniformity and the phonetics-phonology boundary. In M. Broe \& J. Pierrehumbert (eds.), Papers in laboratory phonology V. Acquisition and the lexicon. Cambridge: CUP. 313-334

Tarral, Nikolaus. 1903. Laut- und Formenlehre der Mundart des Kantons Falkenberg in Lothr. Strassburg: Heitz \& Mündel.

Vuillermet, Marine. 2012. A Grammar of Ese Ejja. Dissertation, Université Lumière Lyon 2. 